\title{
Constitutionalising Labour Rights In Canada and Europe: Freedom of Association, Collective Bargaining, and Strikes
}

\author{
Judy Fudge
}

A catalogue of human rights can be an admirable instrument of justice....To enact a bill of rights may involve a shifting of the function of law reform from Parliament, the Government and the Law Commission to the Bench and to the Bar. Some may consider this as a risk, others as an opportunity. But it should be faced with open eyes. The potential significance of such a development should not be underestimated. ${ }^{1}$

\section{Introduction}

Why are unions in Canada and the European Union going to court to claim that the rights to bargain collectively and to strike are fundamental human rights and thus constitutionally protected?2 At the level of immediate legal strategy the answer is obvious. The assumption is that if these collective labour rights are elevated to a fundamental constitutional level and given a hard edge, they will not only save workers from the worst depredations of neo-liberal and austerity policies but also provide a secure basis for resocialising Canada and Europe. ${ }^{3}$ However, from

\footnotetext{
* Judy Fudge, ILO-France Chair/Fellow, Institute of Advanced Studies, Nantes, France; Professor, University of Kent, UK. Email: J.A.Fudge@kent.ac.uk. I am grateful to the Swedish Network for European Studies and the Faculty of Lund for inviting me to present at the 'The EU Charter of Fundamental Rights and the Weak Social Constitution? Theoretical, Constitutional, Comparative and Labour Law Perspectives' conference at Lund University in December 2014, where I received useful feedback and ideas. Thanks go to the audience of Current Legal Problems lecture for their helpful comments and questions, and, in particular, to Diamond Ashiagbor, John Hendy, Ken Massicotte, and Virginia Mantouvalou, as well as to Hanna Eklund, Eric Tucker, and two anonymous reviewers for reading a draft of this article. All errors are my own.

1 O Kahn-Freund, 'The Impact of Constitutions on Labour Law' (1976) 35 The Cambridge Law Journal 241, 270.

2 This project is referred to as 'constitutionalising labour rights' and it has generated an expanding literature. For early contributions see J Fudge, 'The New Discourse of Labour Rights: From Social Economic and Social Rights to Fundamental Rights?'(2007) 29 Comparative Labor Law \& Policy Journal 29; H Collins, 'Utility and Rights in Common Law Reasoning: Rebalancing Private Law through Constitutionalization' (2007) 30 Dalhousie Law Journal 1.

3 P. Macklem, 'The Right to Bargain Collectively in International Law: Workers' Rights, Human Rights, International Rights?' in P Alston (ed), Labour Rights as
} 
a longer term perspective, framing claims to collective action in terms of human rights and advancing such claims in the adjudicative fora of courts is a departure from unions' historical practice of asserting claims to industrial citizenship though democratic politics and by mobilization in the workplace and on the streets. ${ }^{4}$

Ruth Dukes has recently reminded labour law scholars that Kahn-Freund adopted a sociological or socio-legal methodology. ${ }^{5}$ For Kahn-Freund the sociology of law established 'the social effect of the norm, ... the way in which it appears in society and ... its social function'.6 My aim is to take Kahn-Freund's admonition in the epigraph to this paper to heart, and my approach to the question I began by posing is socio-legal and not the normative or philosophical question of what 'the rules that ought to govern definitions of value' are. ${ }^{7}$ My perspective does not gainsay the need to grapple with the complex normative questions that arise when attempting to justify the characterisation of collective labour rights as a type of human right that should be constitutionally protected by courts. However, I believe that it is important to draw back and widen the aperture of analysis in order to appreciate what this shift in the lexicon and grammar of claims making by workers and unions reveals about how rights and courts have become central to how power is legitimated in the contemporary globalised world.

The goal of constitutionalising labour rights is, I will argue, a specific example of the broader and much more pervasive global constitutionalisation that characterises our contemporary world. Global constitutionalism involves a shift in law's legitimacy from constituent power, the will of the people, and democracy to rights in which 'courts are the hinge elements in the emergence of a comprehensive transnational constitutionalism, which integrates and systematically consolidates political institutions operating in the national, supranational and transnational domains of global society'. ${ }^{8}$ I am using Chris Thornhill's sociological functionalist theoretical frame because he is concerned with the functional reality that constitutional norms acquire in the societal environments in which they are

Human Rights (Oxford University Press, 2005) 61, 82-4; N Countouris and M Freedland (eds), Resocialising Europe: In a Time of Crisis (Cambridge 2013). ${ }^{4}$ S Deakin. 'Social Rights in a Globalized Economy' in P Alston (ed), Labour Rights as Human Rights (Oxford University Press 2005); J Fudge, 'The New Discourse of Labour Rights: From Social to Fundamental Rights?' (2007) 29 Comparative Labor Law \& Policy Journal 29.

${ }^{5}$ R Dukes, The Labour Constitution: The Enduring Idea of Labour Law (Oxford University Press 2014) 199.

${ }^{6}$ Dukes (n 5) 199, quoting 0 Kahn Freund, 'Hugo Sinzheimer', '98

${ }^{7} \mathrm{H}$ Becker, What about Mozart? What about Murder? Reasoning from Cases (University of Chicago Press 2014) 176. See G Verschraegen, 'Systems Theory and the Paradox of Human Rights' in M King and C Thornhill, (eds), Luhmann on Law and Politics: Critical Appraisals and Applications (Hart Publishing 2006) 101, 102-3 on the difference between a sociological approach to fundamental rights and the current (dominant) philosophical.

${ }^{8} \mathrm{C}$ Thornhill, 'Rights and Constituent Power in the Global Constitution' (2014) International Journal of Law in Context 357, 367 (emphasis in the original). 
produced. His approach enables us to appreciate the 'nexus between changing norms, changing societal functions and changing demands for law, power and legitimacy'. ${ }^{9}$

I will begin by discussing the legal literature on multiple constitutions, which has highlighted the tension between social and labour rights and economic structures, and I will explain what Thornhill's sociological approach to global constitutionalism adds to the account. I will then turn to examine how international human rights are invoked by trade unions in Canada and the EU to constitutionalize the rights to bargain collectively and to strike, and my specific focus is on how courts deploy these rights in their reasoning and the circulation of international human rights through different adjudicative sites. I will begin by looking at Canada, where unions were early strategic actors lodging complaints with International Labour Organization (ILO) supervisory bodies and urging the Supreme Court to interpret the constitutional protection of freedom of association in line with the position of these institutions. ${ }^{10}$ The central interpretive issue is the relevance of international human rights for interpreting the freedom of association guaranteed in the Canadian Charter of Rights and Freedoms. I will then turn to Europe, where human rights law can best be thought of as a polycentric galaxy, composed of a number of distinct sites and systems that exert gravitational force on one another. ${ }^{11}$ Unions have invoked an array of human rights norms before differently configured institutions, urging them to draw upon each other's pronouncements in order to characterise collective labour rights as fundamental. After discussing how unions' attempts to constitutionalise labour rights at the European level have fared, I will discuss the controversy that has engulfed the ILO's supervisory bodies. The success of unions in both Canada and the EU in invoking ILO instruments and jurisprudence in constitutional courts has precipitated a backlash by employers, who challenge both the legitimacy of the right to strike and the normative authority of the ILO's supervisory machinery. To conclude, I will consider whether the use of international human rights by courts to interpret the scope of freedom of association exacerbates or ameliorates the displacement of democracy and constituent power as a basis of political legitimacy in global constitutionalism.

\section{Global Constitutionalism}

Double Movement and Multiple Constitutionalism

\footnotetext{
9 Ibid. 358.

${ }^{10}$ For a discussion of the composition and roles of the various ILO supervisory bodies see C LaHovary, 'Showdown at the ILO? A Historical Perspective on the Employers' Group's 2012 Challenge to the Right to Strike' (2013) 42 Industrial Law Journal 338.

${ }^{11}$ C Kilpatrick, 'Has Polycentric Strike Law Arrived in the UK? After Laval, After Viking, After Demir' (2014) 30 The International Journal of Comparative Labour Law and Industrial Relations 293.
} 
Using Canada and the EU as illustrations, I have argued that since the 1980s we have witnessed a two-step or double movement of constitutionalism. ${ }^{12} \mathrm{My}$ framework combined the political economy conceptualisation of 'new constitutionalism', ${ }^{13}$ which refers to the process by which markets have expanded throughout the globe, with Karl Polanyi's idea of the 'double movement', whereby 'society protects itself against the perils inherent in a self-regulating market economy'.14 I characterized the attempt since the mid-1990s to constitutionalise labour rights as fundamental human rights at the international, transnational, and national levels as part of the broader movement to swing the pendulum back towards the social dimension of globalization and to re-embed the labour market. ${ }^{15}$ This understanding of 'double movement' constitutionalisation appreciates that the constitutional process is multi-scalar (simultaneously national, transactional, and international), the existence of multiple constitutions (especially the economic and social), and the shift in power and legitimacy from legislative to adjudicative institutions. Thus, it chimes with legal scholarship that emphasizes the multiplicity of constitutions.

In Canada, Harry Arthurs and Eric Tucker have used the idea of multiple constitutions in their accounts of attempts to constitutionalise labour rights. Arthurs offered a taxonomy of constitutions, which he defines as 'a juridical regime that entrenches certain rights in the fundamental laws of the polity'. ${ }^{16}$ He identifies five constitutions: the rights-based, litigation-driven constitution; the valorizing constitution; the political constitution; the economic constitution; and the enterprise constitution. He describes how in Canada the different constitutions are in tension, and he emphasises the challenges of constitutionalising employment relations in global enterprises since it requires 'amending our political, economic and enterprise constitutions' and "re-engineer[ing]" the deep structures of

12 J Fudge, 'Constitutionalizing Labour Rights in Europe' in T Campbell, K Ewing and A Tompkins (eds), The Legal Protection of Human Rights: Sceptical Essays (Oxford University Press 2011) 244-67; J Fudge, 'Brave New Words: Labour, the Courts and The Canadian Charter of Rights and Freedoms' (2010) 28 The Windsor Yearbook Access to Justice 23; Fudge (n 2); J Fudge 'Labour is Not a Commodity: The Supreme Court of Canada and the Freedom of Association' (2004) 67 Saskatchewan Law Review 25.

${ }^{13}$ Stephen Gill coined the term 'new constitutionalism' to refer to the quasi-legal process whereby nation states cede their authority to interfere with the market. S Gill, 'Globalization, Market Civilization, and Disciplinary Neoliberalism' (1995) 24 Millennium: Journal of International Studies 399.

${ }^{14} \mathrm{~K}$ Polanyi, The Great Transformation: The Political and Economic Origins of Our Time (Beacon Press 1944) 76.

15 Fudge, 'Constitutionalizing Labour Rights in Europe' (n 12); J Fudge, 'Legally Speaking: The Courts, the Market, and Democracy' (2003) 19 Supreme Court Law Review (2nd series) 111, 119.

${ }^{16}$ Harry Arthurs, 'The Constitutionalization of Employment Relations: Multiple Models, Pernicious Problems '(2010) 19 Social \& Legal Studies 403, 405. 
society'.17 Tucker concentrates on two constitutions, labour's and capital's, and he contrasts them along three dimensions - thickness (the substance of rights protected), hardness (the enforceability of the rights), and geographic scale. ${ }^{18}$ Like Arthurs, he concludes that capital's constitution is more deeply embedded than labour's 'rights-based' constitution.

In Europe, Kaarlo Tuori has focused on the multiplicity of Europe's constitutions. ${ }^{19}$ Drawing on Luhmann, he emphasises the relational nature of constitutions through which the law relates to a constitutional object and establishes a constitutional relation. ${ }^{20}$ Tuori proposes a European-level taxonomy of constitutions based on their object: the economic constitution, which concerns the relation of law to the fundamentals of the economic system; the juridical constitution which comprises the fundamental features of the legal system; the political constitution, whereby the law constitutes and regulates the political system; and the security constitution, which addresses society's internal and external security risks. ${ }^{21}$ He explains that there are relations of implication, which can also be conflictual, between the different aspects of the constitution. These conflicts often take the form of clashes between different types of rights, and, according to Tuori, the 'functional primacy of the economic constitution is manifest by the manner in which these clashes are framed as legal issues' by the Court of Justice. ${ }^{22}$

These accounts of constitutionalism capture its multiplicity and the dominance of the economic constitution, but the problem is that they do not sufficiently link the different movements or constitutions to changes in society. Thornhill's sociological functionalist approach to constitutionalism addresses this gap since it explicitly connects the processes of global constitutionalism to changes in social structure.

\section{Global Constitutionalism, Rights, and Courts}

Thornhill adopts a modified version of Luhmann's system theory for his account of constitutional norms. Like Luhmann, instead of seeing constitutions as materialized principles, he conceptualizes them as reflexive adaptive meanings in

\footnotetext{
17 Ibid. 416

18 Eric Tucker, 'Labor's Many Constitutions (and Capital's too)' (2012) 33 Comparative labor Law and Policy Journal 355.

${ }^{19} \mathrm{~K}$ Tuori, 'The Many Constitutions of Europe' in K Tuori and S Sankaran (eds), The Many Constitutions of Europe (Ashgate 2010) 1.

20 Ibid. 9. However, having used Luhmann's systems-theoretical approach to develop his idea of multiple constitutions, Tuori drops it on the ground that the notion of structural coupling, while apt for politics and law, cannot address the social constitution.

21 Ibid. 8.

${ }^{22} \mathrm{~K}$ Tuori, The Economic Constitution Among European Constitutions, Helsinki Legal Studies Research Paper No. 6, 2011, 39

<http://papers.ssrn.com/sol3/papers.cfm?abstract_id=1844285> accessed 27 February 2015.
} 
light of changes in societal structure and evolving demands for political power and law in an increasingly complex, heterogeneous, and interlinked world. ${ }^{23}$ However, unlike Luhmann, Thornhill considers certain legal norms as indispensible for certain historical époques and regards legal and political systems as homologous rather than distinct. ${ }^{24} \mathrm{He}$ also regards the function of the constitution as a distinctly political, in that it produces, restricts, and refines power utilized by states, supranational polities, and the transnational political system. ${ }^{25}$

Focusing on the norms of constituent power and rights, Thornhill contrasts classical national constitutionalism to global constitutionalism. The central normative principle of national constitutionalism is the doctrine of constituent power - that is, that legitimate political power is founded though the original exercise of a single popular will. Referring to revolutionary America and revolutionary Europe, he argues that the idea of constituent power, or the will of the people, provided a centralized sovereign state with plenary power. ${ }^{26}$ Rights are also a crucial element of classical constitutionalism and Thornhill explains that rights and constituent power are dialectically interwoven. At the same time as rights accentuate the inclusiveness of the modern political system (the expansion of rights bearers for example from propertied white men to propertyless men and then to women), they also establish the boundaries of the political system. Classical civil liberties preserve the different social systems - such as the economy, religion, and the media - from intrusion by political power. Rights enable courts to police the boundaries between the political system and its social environment. The modern democratic state's constitutional formula of constituent power and the constituted power of rights was internally adaptive as it enabled the political system to meet rising demands for legislation, build reliable normative structures, and stabilize autonomous subsystems. ${ }^{27}$

By contrast, in the contemporary global society, constituent power no longer legitimates political power and law. Law making and applying institutions extend across different geographic scales, some of which have a very attenuated connection with democratic processes. For supranational polities, the idea of constituent power as a basis for political legitimacy has always been weak. ${ }^{28}$ In the EU, the premier

23 Thornhill (n 8) 359.

24 Ibid., 358-9

25 Chris Thornhill, A Sociology of Constitutions: Constitutions and State Legitimacy in Historical-Sociological Perspective (Cambridge University Press 2011) 11; Thornhill (n 9). This position contrasts with that of Gunther Teubner, who emphasises societal constitutionalism, see Constitutional Fragments: Societal Constitutionalism and Globalization (Oxford University Press, 2012). For a discussion of these authors' positions see J Priban, 'Constitutionalism as Fear of the Political? A Comparative Analysis of Teubner's Constitutional Fragments and Thornhill's A Sociology of Constitutions' (2012) Journal of Law and Society 441

${ }^{26} \mathrm{C}$ Thornhill, 'A Sociology of Constituent Power: The Political Code of Transnational Societal Constitutions' (2013) 20 Indiana Journal of Global Legal Studies 551.

27 Thornhill (n 8) 374-6

28 A Somek, 'The Darling Dogma of Bourgeois Europeanists' (2014) 30 European 
example of a supranational polity, the Court of Justice of the European Union (CJEU) has, by declaring the doctrine of direct effect and the supremacy of EU law, assumed the authority to produce a supranational constitution for European Member States. ${ }^{29}$ The basis of the CJEU's authority (and legitimacy) for Member State national courts is its invocation of rights jurisprudence..$^{30}$ In combination with the European Court of Human Rights and national courts, the CJEU relies upon human rights to check the constituent power of Member States and authorise and legitimate legislative acts that are precariously supported by democratic principles. The combination of the binding force of the Charter of Fundamental Rights, the ever-expanding scope of EU powers and competencies into areas that touch more directly on human rights, and the extension of the CJEU's jurisdiction by the Lisbon Treaty heralds a growing human rights role for the Court. ${ }^{31}$

At the national level, constitutional courts armed with the power of judicial review appeal to international human rights as a basis for legitimating their decisions. In Canada, the most significant constitutional amendment was the entrenchment of the Charter of Rights and Freedoms in 1982, which dramatically enhanced the prominence of the Supreme Court of Canada. The Charter has revolutionized Canadian political life, forcing legislatures into a dialogical relationship with judges in which rights are the leitmotif. ${ }^{32}$ The Supreme Court is a leader among national courts in referring to regional and international human rights and the rulings of other courts in developing a national constitutional order. ${ }^{33}$

The rise of international or transnational rights as a basis of legal and political structures is the most distinctive aspect in contemporary constitutionalism. Judicial institutions have increased legitimacy and power, and rights increasingly are inner-judicial constructs as constitutional bodies elaborate norms increasingly through reference to the decisions of transnational and international bodies rather than by involving constituent power. This shift is according to Thornhill, a selfreflexive reformulation of the political system, which enables it to obtain and express new sources of authority to sustain its mobilization and its acts of legislation. The reliance on the interpretation of rights by international bodies enables the global political system to conduct 'its exchanges at many societal levels, over quickly widening cultural and geographic distances and in the absence of

Law Journal 288.

${ }^{29}$ Thornhill (n 8) 366: D Schiek, Economic and Social Integration: The Challenge of EU Constitutional Law (Edward Elgar 2012) 65-8, 30 Schiek (n 29) 98.

${ }^{31}$ G De Búrca, 'After the EU Charter of Fundamental Rights: The Court of Justice as a Human Rights Adjudicator? (2013) 20 Maastricht Journal of European and Comparative Law 168.

${ }^{32}$ V Radmilovic, 'Strategic Legitimacy Cultivation at the Supreme Court of Canada: Quebec Secession Reference and Beyond' (2010) 43 Canadian Journal of Political Science 843.

${ }^{33}$ P Macklem, 'The International Constitution' in F Faraday, J Fudge, and E Tucker (eds), Constitutional Labour Rights in Canada: From Farm Workers to the Fraser Case (Irwin Law books 2012) 
predictable or objective support or justification in national societies and their politically assembled constituencies'. ${ }^{34}$

Global constitutionalism does not so much constitute a break with classical constitutionalism, but a reformulation; the key elements remain but they have been reordered and re-interpreted. Constituent democratic volition persists, but increasingly the invocation of rights allows the political system to dispense with the external dimensions of democracy without losing its legitimacy. Judicial actors and other adjudicative bodies apply internally authorized norms - influenced by international rights jurisprudence - as a ground for legal validity. In Canada, for example, the increased importance and power of the Supreme Court does not entail that the power of other political actors has diminished. What it means, however, is that the way political actors exercise and legitimate their power has changed. In delineating the boundaries of the constitutional protection of rights, the Supreme Court of Canada has cultivated 'legitimacy by exhibiting strategic sensitivities to factors operating in the external, political environment.'35 Elected governments and courts are engaged in a complex interaction that blurs the government's responsibility for policy outcomes. ${ }^{36}$ Rights and constituent power serve the same function, both are constitutional formulas that enable political institutions to maintain their autonomy and enhance their power. Moreover, the rise of rights both accompanies and facilitates the 'growing differentiation and increasing internalism of the distinct functional domains of global society'. ${ }^{37}$

From a systems-theoretical perspective, fundamental rights serve two critical functions in a complex and pluralist society. ${ }^{38}$ They ensure that the differentiation between different functional subsystems - the economy, religion, politics - is maintained, while they simultaneously enable individuals to participate in different subsystems as subjective rights holders with the equal right of inclusion and participation. The fact that fundamental or human rights are multivalent and there is no clear hierarchical legal order only adds to their potency. ${ }^{39}$ In effect, the rights/not rights code enables 'the political system to generate more power in order to cover its exchanges through society, and it allows it to transmit this power in a highly recursive fashion', 40 As constituent power is attenuated in the context of

\footnotetext{
34 Thornhill (n 8) 373.

35 Radmilovic (n 32) 844.

${ }^{36}$ V Radmilovic, 'Governmental Interventions and Judicial Decision Making: The Supreme Court of Canada in the Age of the Charter' (2013) 46 Canadian Journal of Political Science 323; Radmilovic (n 32); M Hennigar, 'Exploring Complex JudicialExecutive Interaction: Federal Government Concessions in Charter of Rights Cases' (2010) 43 Canadian Journal of Political Science 821.

37 Thornhill (n 8) 375, italics in original, footnote omitted.

38 Verschraegen (n 7) 101.

${ }^{39}$ S Bresson, 'European Human Rights Pluralism: Notion and Justification' in M Maduro, K Tuori and S Sanakri (eds), Transnational law: Rethinking European Law and Legal Thinking (Cambridge University Press, 2014); N Luhmann, Law as a Social System K A Ziegert (trans) (Oxford University Press 2004) 136.

40 Thornhill (n 26) 585.
} 
contemporary globalism, political power is legitimated through recourse to rights. While other social actors can invoke rights to check the power of the state, the state has a range of ways in which it can respond to successful rights challenges.

Despite the fact that the polyarchical constitution lacks a firm societal or volitional foundation, at each of its levels the courts, other judicial actors, and private agents recognize and apply rights as structural points of orientation and thereby providing a degree of internal cohesion..$^{41}$ If fundamental rights are understood as the distinctive code of global constitutionalism, they constitute the element that enables the different constitutional subsystems to communicate, albeit in a manner that it contingent. But, the fact that rights are the pre-eminent form of legitimacy does not mean that conflict has been eliminated; instead it has been reconfigured and repositioned. The relationship between different judicial orders is fractious since rights and courts are plural and polycentric, and the structural role of rights fuels the growing culture of litigation. ${ }^{42}$ As Alain Supiot put it, 'juridical devices specific to democracy, whether electoral freedoms or freedom of association, make it possible to process the stuff of political and social unrest and to convert tests of strength into test cases'. ${ }^{43}$

\section{Constitutonalising Labour Rights}

\section{Canada: A Strategic Approach}

In Canada, the labour movement did not participate in the constitutional drafting process and, thus, made no attempt to influence the wording of the Charter's guarantee of freedom of association. ${ }^{44}$ However, unions were quick to initiate litigation invoking the freedom of association. In 1982, the same year that the Charter was entrenched, the federal and several provincial governments introduced a wide range of severe restrictions on collective bargaining and collective action as part of a monetarist agenda. ${ }^{45}$ Unions went to court and argued that freedom of association guaranteed by the brand new Charter should be interpreted in line with international human rights, especially International Labour

\footnotetext{
41 Ibid. 578.

42 Transnational constitutionalism is characterized by vertical or multilevel pluralism in that national courts rely on the interpretation of rights by transnational or international courts as well as a horizontal or multifocal pluralism since different judicial actors (at the same or different levels) contest jurisdictional authority with one another. Thornhill (n 26) 575-6.

43 A Supiot, 'Europe won over to the "communist market economy', Viking-LavalRüffert: Economic freedoms versus fundamental social rights - where does the balance lie? Debate organised by Notre Europe and the European Trade Union Institute $<$ http://www.institutdelors.eu/media/supiot-en.pdf?pdf $=0 \mathrm{k}>$ accessed 27 February 2015. 44 L Savage, 'Organized Labour and the Canadian Charter of Rights and Freedoms' (2007) 36 Sup. Ct. L. Rev. 175.

45 Fudge, 'Labour is Not a Commodity' (n 12).
} 
Conventions, that protect the rights to bargain collectively and to strike. ${ }^{46}$

At the same time as they went to court, Canadian unions complained to the ILO's supervisory bodies that governments across the country were violating the freedom of association. In fact, they outpaced all other national labour movements in lodging complaints with the International Labour Organization. ${ }^{47}$ Of the 76 complaints pertaining to Canada that the ILO's Committee on Freedom of Association (CFA) decided between 1982 and 2008, the Committee found Canada in violation of its obligations in 71 , making it the subject of the highest number of valid complaints of the 183 member states of the ILO. Nevertheless, this dismal record does not necessarily mean that Canadian governments were particularly egregious in trampling on labour rights; it could also mean that Canadian unions were particularly adept at filing complaints. For the most part, Canadian governments responded to the complaints by ignoring the ILO's findings and recommendations. ${ }^{48}$

So, too, did the Supreme Court of Canada, despite attempts by trade unions to persuade the Court that Canada's obligation to respect ILO conventions should be the basis for interpreting the constitutional protection of freedom of association. Between 1987 and 2001, a majority of the Court simply ignored international labour rights and held that neither the right to strike nor the right to bargain collectively fell within freedom of association protected by the Charter. But, beginning in 2001, the Court changed tack and began to use international labour rights both to distance itself from pervious decisions and incrementally to expand the freedom of association to include elements of collective bargaining.

\section{Ignoring International Human Rights}

The Supreme Court of Canada's first three decisions interpreting section 2(d), which were released together in 1987 and came to be known as the Labour Trilogy, were marked by sharp disagreement over whether or not freedom

\footnotetext{
${ }^{46}$ Part I of the Constitution Act, 1982, being Schedule B to the Canada Act 1982 (U.K.), 1982, c. 11. The Canadian Charter of Rights and Freedoms is similar in many respects to the European Convention on Human Rights; it primarily protects civil and political rights, it applies vertically, and it has an explicit two-part structure of rights definition followed by justifiable limitation. It also provides a mechanism, which is rarely used, for legislatures to adopt legislation that expressly 'overrides' the operation of key Charter rights regarding a statute or a statutory provision. ${ }^{47}$ M Choko, 'The Dialogue between Canada and the ILO on Freedom of Association: What Remains after Fraser?' (2012) 28 The International Journal of Comparative Labour Law and Industrial Relations 397, 401; B Burkett, J Craig and J Gallagher, Canada and the ILO: Freedom of Association since 1982' (2003) 10 Canadian Labour and Employment Law Journal 231,251-2

${ }^{48}$ Choko (n 47) 402; S L Kang, Human Rights and Labor Solidarity: Trade Unions in the Global Economy (University of Pennsylvania Press, 2012) 173-6.
} 
of association included the right to strike and to bargain collectively. ${ }^{49}$ The main reasons were delivered in the Alberta Reference, a case involving compulsory arbitration to resolve impasses in collective bargaining and a prohibition on strikes in the public sector. ${ }^{50}$

The treatment of international law in interpreting the scope of freedom of association was the fault line between the majority and dissenting judgments. The majority of the judges simply ignored it, and adopted a narrow approach to the scope of activities protected by the freedom of association, emphasizing the need for the state to be neutral when it came to different types of association and limiting the protection of associational activities to the exercise of fundamental rights or what individuals could do lawfully. The Court held that neither the rights to bargain collectively nor to strike were protected by the Charter.

By contrast, in his dissent Chief Justice Dickson used international law to support his contextual and purposive approach to freedom of association and his conclusion that collective bargaining and striking were included under the freedom of association protected in the Charter. Although he was clear that the judiciary was 'not bound by the norms of international law in interpreting the Charter', he declared 'the Charter should generally be presumed to provide protection at least as great as that afforded by similar provisions in international human rights documents which Canada has ratified'.51 Dickson C.J. noted that Canada had acceded to both of the United Nations international covenants, noting that both contained specific provisions relating to freedom of association and trade unions. ${ }^{52}$ Moreover, he referred to the ILO Convention 87 regarding the freedom of association, and the observations of the ILO supervisory bodies relating the legislation that was the subject of the constitutional challenges. He noted 'there is a clear consensus amongst the ILO adjudicative bodies that Convention No. 87 goes beyond merely protecting the formation of labour unions and provides protection of their essential activities - that is of collective bargaining and the freedom to strike'. ${ }^{53}$ He treated the right to strike as an essential element of collective bargaining, and it was for this

49 The Labour Trilogy refers to three concurrently released appeals: Reference re Public Service Employee Relations Act (Alta.), [1987] 1 S.C.R. 313; PSAC v. Canada, [1987] 1 S.C.R. 424 (S.C.C.); and RWDSU v. Saskatchewan [1987] 1 S.C.R. 460 (S.C.C.). 50 of the six justices participating in the case, three held that collective bargaining was not protected by section 2 (d), four held that strike activity was excluded, and two dissented. For a detailed discussion of these cases see J Fudge, 'Freedom of Association' in S Beaulac and E Mendes (eds), Canadian Charter of Rights and Freedoms ( $5^{\text {th }}$ ed.) (Toronto: LexisNexis, 2013) 5.

51 Alberta Reference, n 49, 59.

52 International Covenant on Economic, Social and Cultural Right, G.A. Res. 2200 A (XXI), 21 U.N. GAOR, Supp. (No. 16) 49, U.N. Doc. A/6316 (1966)) and International Covenant on Civil and Political Rights, G.A. Res. 2200 A (XXI), 21 U.N. GAOR, Supp. (No. 16) 52, U.N. Doc. A/6316 (1966).

${ }^{53}$ Alberta Reference (n 49) 355-58, 359. Canada has not ratified Convention 98 on collective bargaining. 
reason that he considered strike activity to be protected by section 2 (d). ${ }^{54}$ However, this expansive approach to the definition of freedom of association was counterbalanced by Dickson's C.J.'s deferential treatment of the government's policy objectives and means. ${ }^{55}$ Only the absolute prohibition on strikes by public sector workers, which had already been found to be contrary to Convention 87 by the ILO's Committee of Experts on the Application of Conventions and Recommendations (CEACR), did not survive constitutional scrutiny. ${ }^{56}$

\section{Taking International Labour Rights Seriously}

Although he failed to 'attract sufficient collegial support to lift his views out of their dissenting status', Dickson C.J.'s approach to Canada's commitments under international law has, 'more recently proven to be a magnetic guide'. ${ }^{57}$ Its pull was first felt in 2001 when the Supreme Court of Canada invoked Dickson C.J.'s dissent as the inspiration for relying on international labour law and human rights for the interpretation of freedom of association in the labour context. At stake in Dunmore $v$. Ontario was whether or not the government of Ontario was under a positive obligation to provide legislative protection to agricultural workers to enable them to join and participate in trade unions without fear of employer retaliation. ${ }^{58}$ Mindful of the array of unfavourable precedents, the union that launched the constitutional challenge adopted an incremental strategy, and did not ask for full collective bargaining rights. In expanding the interpretation of freedom of association to include such collective activities as making collective representations to an employer, the Court referred to international human rights and the observations of ILO supervisory bodies as interpretive sources. ${ }^{59}$ But, despite explicit reference to the ILO's Committee on Freedom of Association's observation that the exclusion of agricultural workers from collective bargaining was in violation of Canada's obligations under Convention 87, the Court did not extend its interpretation of freedom of association to include collective bargaining. ${ }^{60}$ The Court's truncated interpretation of freedom of association suggests that there may be some disadvantages for unions when they take a cautious and incremental approach to litigation.

\footnotetext{
54 Ibid. 371.

55 Wilson J. adopted a less deferential stance in both PSAC (n 49) and RWDSU (n 49). 56 Alberta Reference (n 49) 375, citing Freedom of Association andCollective Bargaining: General Survey by the Committee of Experts in the Application of Conventions and Recommendations, Report III (Part 4B), ILO Geneva, 1983. 57 Saskatchewan Federation of Labour v. Saskatchewan, 2015 SCC 4, para 63. 58 Dunmore v. Ontario (Attorney General), [2001] S.C.J. No. 87, [2001] 3 S.C.R. 1016 (S.C.C.)

59 Ibid. para.. 41.

60 Ibid. para. 41, referring to Report in which the committee requests to be kept informed of development - Report No 308, November 1997 Case No 1900 (Canada) Complaint date: 23-AUG-96 - Closed.
} 
In 2007, the Supreme Court overturned the precedent established twenty years earlier in the Labour Trilogy that collective bargaining was not protected by freedom of association. ${ }^{61}$ The case, known as Health Services, involved a constitutional challenge to legislation that invalidated key provisions in collective agreements in the health services sector and precluded collective bargaining on significant issues. As the litigation wound its way through the courts, the BC government was dismissive both of the unions' complaint to the ILO and cavalier with the ILO's processes. The provincial government position was that the unions' complaints were 'fundamentally frivolous, vexatious, mostly driven by political motivation, and completely without merit'.62 It also questioned the legitimacy of the ILO as the appropriate institutional setting for examining the legislation, noting that Bill 29 had passed through 'democratic processes' and that its constitutionality was before domestic courts. After the court at the first level upheld the legislation's constitutionality, the provincial government simply announced that it had no intention of amending the legislation in light of the CFA's observation that it had not met its obligations and refused to respond to requests from the ILO for follow up communications. ${ }^{63}$

The majority decision in Health Services, which was written by McLachlin C.J. and Le Bel J., characterised Dunmore as marking a new direction in freedom of association jurisprudence and expanded the activities protected under freedom of association to include aspects of collective bargaining, specifically the duty to bargain in good faith. It adopted the position staked out by Dickson C.J. in his dissent in the Alberta Reference to international human rights instruments that Canada has ratified; although not binding they provide an important normative resource for interpreting the Charter' freedom of association. ${ }^{64}$ The Court also noted the IL0's three main supervisory bodies, the CFA, the CEACR, and the Commission of Inquiry, had interpreted Convention 87 to include collective bargaining. ${ }^{65} \mathrm{But}$, in light of the wide range of international legal sources to which it referred, it is striking that the Court omitted any reference to the recommendations of the CFA regarding the legislation in dispute. Equally remarkable is just how limited the right to collective bargaining that the Court considered to be protected by the Charter and the extent to which it departs from the understandings of the ILO supervisory bodies. ${ }^{66}$ It also specifically mentioned that the case did not involve the right to strike, which had been considered in the Labour Trilogy ${ }^{67}$

${ }^{61}$ Health Services and Support - Facilities Subsector Bargaining Association v British Columbia [2007] 2 SCR 391. para 35.

${ }^{62}$ Kang (n 48) 174.

63 Case No. 2180, Report No 330 (Canada). Choko (n 47) 404-5; Kang (n 48) 173-4. ${ }^{64}$ Ibid. at paras. 73-75. International Covenant on Economic, Social and Cultural Rights, 993 U.N.T.S. 3, Can. T.S. 1976, No. 46, and International Covenant on Civil and Political Rights 999 U.N.T.S. 171, Can. T.S. 1976, No. 47.

${ }^{65}$ Health Services (n 61) para. 76.

${ }^{66}$ Choko (n 47) 412-7.

${ }^{67}$ Health Services (n 61) para. 19. 
The combination of broad statements in support of collective bargaining and a narrow holding about what aspects of collective bargaining were actually protected invited confusion, and precipitated a rash of critical legal commentary as well as a great deal of litigation. Unions launched constitutional challenges to public sectors wage controls, restrictions on their ability to democratically select their representatives, and restrictions on their right to strike. 68

An on-going dispute involving the legislative response to the Dunmore was the first case after Health Services in which the Supreme Court was faced with delineating the scope of constitutionally protected collective bargaining rights. The issue in Attorney General of Ontario v. Fraser was the constitutionality of Agricultural Employee Protection Act (AEPA), which was carefully crafted to meet the narrowest interpretation of the constitutional requirements set out in the Dunmore decision. ${ }^{69}$ The question before the Supreme Court in Fraser was whether the AEPA, which did not require the employer to bargain in good faith with agricultural workers representatives, was constitutional in light of Health Services, which appeared to require, in addition to protection of the right to organize, a duty on the employer to bargain in good faith. Eight of the nine members of the Supreme Court held that the legislation did. ${ }^{70}$ However, the Court was badly divided over the scope of protection that freedom of association provides to the right to bargain collectively. ${ }^{71}$

The majority's use of international labour law in Fraser was purely to defend its decision in Health Services in the face of a concerted attack by Justice Rothstein, who also questioned the validity of the majority's handling of international labour law. While the majority's decision referred to the CFA's observation that the legislation in dispute did not conform to Convention 87, although they made no mention of it in Health Services, it ignored the CFA's interim observations regarding the AEPA's conformity to the principles of freedom of association. ${ }^{72}$

Fraser sheds light on the sometimes-fraught relations between national courts and the ILO's supervisory bodies when it comes to the meaning of freedom of association. The union that initiated the litigation in Fraser also brought a complaint to the CFA that the AEPA was in violation of freedom of association. In dealing with the union's earlier complaint that the legislation that was at issue in Dunmore violated Convention 87, the CFA decided to proceed with the complaint before the

68 Canadian Labour Rights Foundation, Summary of current Charter challenges and their impact on union security in Canada, March 2015

<http://labourrights.ca/sites/labourrights.ca/files/documents/summary current c ases march 2015.pdf > accessed 11 March 2015.

692011 SCC 20.

70 Ibid. para. 107.

${ }^{71}$ For a discussion see J Fudge, 'Constitutional Rights, Collective Bargaining and the Supreme Court of Canada: Retreat and Reversal in the Fraser Case' (2011) 41 Indus. L.J. 23.

72 Fraser (n 69) para 94. The interim Report was part of the record. Case No 2704 (Canada): Interim Report in Reports of the Committee on Freedom of Association, 358th Report, ILOOR, 309th Sess., GB.309/8 (November 2010) 335, at para. 361 
Supreme Court of Canada rendered its decision regarding the legislation's constitutionality. By contrast, with respect to the complaint that accompanied the Fraser litigation, the CFA acceded to the Canadian government's request to postpone reaching its final conclusions and recommendations about whether the AEPA conformed to the principles of freedom of association until after it received the Supreme Court's decision. ${ }^{73}$ Noting that it was not bound by domestic judicial decisions, in its interim observations the CFA emphasised the absence of both successfully negotiated collective agreements under the AEPA and any machinery for the promotion of collective bargaining. ${ }^{74}$

After receiving the Fraser decision, which ignored its interim observations, the CFA issued its conclusions regarding the conformity of the AEPA to the principles of freedom of association enshrined in the relevant conventions. Emphasing that its mandate was not to determine the constitutionality of the legislation under the Canadian Charter, the Committee welcomed 'the finding of the Supreme Court that agricultural employers have the duty to consider employee representations in good faith', but it went on to state that it 'is of the opinion that this duty, whether implicit or explicit, is insufficient to ensure the collective bargaining rights of agricultural workers under the principles of freedom of association'.75 The CEACR also noted with regret that the government of Ontario was not considering amendments to the AEPA aimed at ensuring sufficient guarantees for the full exercise of freedom of association, including recourse to industrial actions without sanction. ${ }^{76}$

Fraser marked a hiatus in, and not a halt to, the incremental expansion of the scope of protection provided by the guarantee of freedom of association in the jurisprudence that began in Dunmore. ${ }^{77}$ It also signaled the unwillingness of the Supreme Court to interfere with government machinery for supporting collective bargaining, even if the mechanisms the government has selected has been found by ILO supervisory bodies to fall short of ensuring that workers enjoy the freedom to

73 Choko (n 47) 413-4

${ }^{74}$ Case No. 2704 Report No. 358,Vol. XCIII, 2010, Series B, No. 3, para. 358.

75 Ibid., para. 398.

${ }^{76}$ Observations of the CEACR adopted in 2012, published in 101sr ILC session (2012) Repeated concerns in 2012, which was published in 103 ILC session 2013 77 In Mounted Police Association of Ontario v. Canada (Attorney General) 2015 SCC 1, the Court held that collective bargaining included the right to independent and freely chosen representatives, and it took pains to make it clear that Fraser did not narrow the scope of constitutionally protected collective bargaining. Notably the Court did not refer to any international human rights in its reasons, which is likely due to the fact that the complainants were members of the Royal Canadian Mounted Police and they did not lodge any complaints with the ILO supervisory committees since Convention 87, Article 9 provides that national laws govern with respect to the armed forces and the police. However, in a companion decision, Meredith v. Canada (Attorney General), 2015 SCC 2, the Court held that wage control legislation did not violate freedom of association since it did not constitute a substantial interference with collective bargaining. 
associate. This reluctance on the part of the Court was confirmed in Saskatchewan Federation of Labour v Saskatchewan, where in a brief four paragraphs the Court agreed with the trial judge that 'amendments to the process by which trade unions obtain (or lose) the status of bargaining representative ...does not substantially interfere with the freedom to freely create or join association'. ${ }^{78}$

Despite its narrow approach to collective bargaining rights, the high-water mark of the Supreme Court's embrace of international labour rights as a basis for interpreting of the Charter's protection of freedom of association is Saskatchewan Federation of Labour, where the Court ruled (by a five to two majority) that the right to strike is constitutionally protected..$^{79}$ Writing for the majority, Justice Abella began her decision by referring to the Court's jurisprudence since the Alberta Reference, remarking that 'clearly the arc bends increasingly towards workplace justice'. ${ }^{80}$ Overshadowing the issue of the constitutionality of legislation that made it more difficult for workers to bargain collectively was the question of the constitutionality of provincial legislation that unilaterally designated public sector workers as essential and prohibited them from striking. The legislation did not provide a process for an independent tribunal to review whether or not the work performed by the designated workers was in fact necessary to prevent danger to life, health, and safety. Nor did it provide a meaningful process for resolving collective bargaining disputes that went to impasse. Deploying the approach adopted in Health Services, which established that collective bargaining was protected under freedom of association in the Charter, the Court concluded that the right to strike was a constitutionally protected component of collective bargaining. Recognising that protecting health and safety was a legitimate and pressing objective, Justice Abella nonetheless held that the provincial government had failed to establish that the means that it adopted to achieve this goal were 'minimally impairing' of the constitutional right.

Referring to Dickson C.J.'s dissent in the Alberta Reference, Justice Abella asserted that Canada's international human rights obligations also mandate protecting the right to strike as part of a meaningful process of collective bargaining. ${ }^{81}$ She referred to the explicit protections of the right to strike in International Covenant on Economic, Social, and Cultural Rights and the Charter of the Organization of American States; the nonbinding, but persuasive decisions of the ILO supervisory bodies that freedom of association includes the right to strike; and the International Covenant on Civil and Political Rights, which incorporates

${ }^{78}$ Saskatchewan Federation of Labour (n 57) paras. 199, 199-102. The CFA (Case no 2645 (2010), see Reports of the Committee on Freedom of Association 371 ${ }^{\text {st }}$ Report of the Committee on Freedom of Association Governing Body $320^{\text {th }}$ Session, Geneva, 13-27 March 2014 GB.320/INS/12, 8-9 to which the CEARC referred Observation (CEACR) - adopted 2012, published 102nd ILC session (2013) considered the Trade Union Amendment Act to violate the principles of freedom of association.

${ }^{79}$ Saskatchewan Federation of Labour (n 57).

${ }^{80}$ Ibid. para. 1.

${ }^{81}$ Saskatchewan Federation of Labour (n 57) para. 62, citing Alberta Reference (n 49) 359. 
Convention No. 87 and the obligations it sets out. ${ }^{82}$ As additional support, she pointed out the 'emerging international consensus' that meaningful collective bargaining includes the right to strike. ${ }^{83}$ However, she made no reference to the observations of the CFA or CEACR that the legislation violated the principles of freedom of association, which she also ignored with respect to the denial of collective bargaining rights.

The Supreme Court of Canada has a clear practice of invoking the international labour rights that Canada has ratified to justify a change in the general direction of the jurisprudence, and it has begun to engage with the underlying values embodied in the international human rights instruments. But, while the Court refers to international labour and human rights instruments and their interpretation by ILO supervisory bodies in order to give meaning to the freedom of association, at the same time it ignores the observations of those bodies regarding the specific legislation whose constitutionality is before it. This interpretive technique allows the Court to preserve its exclusive jurisdiction, which is to determine the constitutionality of legislation or government action that is brought before it for scrutiny, instead of de facto delegating this role to ILO supervisory bodies by simply adopting their decisions. It also provides the Court with room to manoeuver since its decisions, unlike the ILO supervisory bodies, require governments to respond. Moreover, with the exception of Rothstein J., the Supreme Court has refused to question the competencies or approaches of the different human rights bodies that interpret and apply international labour and human rights instruments in light of the Employers' Group challenge to the authority of the CEACR and to the legal status of the right to strike. However, the recurring question is whether the federal and provincial governments will continue to refuse to implement the recommendations of ILO supervisory bodies in light of the more robust approach that the Supreme Court has taken to collective labour rights.

\section{Europe' Polycentric Human Rights Galaxy}

The first phase of constitutionalizing labour rights in what is now the legal space of the European Union was exhortatory rather than justiciable. In 1989, the European Council, with the UK dissenting, solemnly declared the Charter of Fundamental Social Rights of Workers. The Workers' Charter did not create new rights nor provide new legal claims, and it was not legally binding on Community institutions or upon Member States. Although it included the right of association, the right to negotiate and conclude collective agreements, and the right to take collective action, these rights were subject to 'conditions laid down by national

82 Ibid. para. 65-70.

83 Abella J. also referred to ECtHR decisions of Demir v. Turkey and Enerji Yapi-Yol Sen v. Turquie, German and Israeli court decisions, and constitutional protections of right to strike in France, Italy, Portugal and South Africa. Ibid. para 71 to 74. 
legislation and practice'. ${ }^{84}$ However, the Workers' Charter served to legitimate collective labour rights within European law. In 2000, it was succeeded by the Charter of Fundamental Rights of the European Union, which also contains a suite of (differently worded) collective labour rights. ${ }^{85}$ Initially, the Charter was a proclamation by the European Parliament, Council, and Commission, and did not establish any new power or task for the Commission or Member States of the Union, or modify the powers or tasks defined by the Treaties. Moreover, several Member States made constitutional reservations to it, and great care was taken to assure Member States that it did not grant greater labour rights than already conferred. However, the EU Charter was seen as elevating the status of collective labour rights in the European legal firmament and it can be used as an interpretive tool. ${ }^{86}$

The second phase of the project of constitutionalising labour rights was marked by the attempt to use international and European rights to give labour rights a hard edge. It was precipitated by legal actions brought by employers who sought to use free movement rights to restrict collective action by unions. In defense of their right to take collective action, unions invoked international and European human rights in order to persuade the European Court of Justice (ECJ) that labour rights were fundamental and took precedence over free movement. This phase spilled outside the EU proper. Instead of simply invoking international and European human rights norms before EU institutions, increasingly European unions began to take complaints to the institutions of the Council of Europe, specifically the European Court of Human Rights and the European Committee on Social Rights, and the supervisory bodies of the ILO.

\section{Economic Freedoms and Fundamental Rights}

Although some commentators recognized that with the enlargement of the EU to include member states with much lower wage and social standard there was a real possibility of 'judicial review of social and labour legislation to test its compatibility with market rules', the actions brought by employers directly against trade unions alleging that their collective action was in violation of their free movement rights was greeted with surprise. ${ }^{87}$ In 2006 , two national courts asked the ECJ to determine the extent to which trade union collective action may operate as a legitimate constraint on employers' freedoms under Community law. In a context in which employers, and not unions, were posing the questions and market access was the primary objective, trade unions invoked international and European

${ }^{84}$ B Hepple, Labour Laws and Global Trade (Hart Publishing 2005) 241-3.

85 See Article $28 \mathrm{~b}$.

${ }^{86}$ P. Syrpis, 'The Treaty of Lisbon; Much Ado ... But about What?' (2008) 27

Industrial Law Journal 219; B Bercusson, European Labour Law, 2nd edn (Cambridge University Press 2009), ch 11; C. Barnard, EC Employment Law, 3rd edn (Oxford University Press 2006) 31-2; J Kenner, EU Employment Law: From Rome to Amsterdam and beyond (Hart Publishing 2008).

${ }^{87}$ Hepple (n 84) 213. 
human rights in order to persuade the Court that the right to strike was so fundamental that it should take precedence over free movement.

Viking was a classic case of an establishment moving across borders in order to gain access to cheaper labour and a union federation and its affiliates engaging in transnational collective action to prevent it. ${ }^{88}$ Laval, by contrast, was a case of a service provider crossing borders and using home state workers who were paid at lower rates than host state workers and the host state workers' union resorting to collective action to insist that the service provider apply its collective agreement to the workers it had posted to the host state. ${ }^{89}$ In both cases the employers brought actions to national courts arguing that, even if lawful under domestic law, the unions' actions breached free movement provisions in the Treaty, the freedom of establishment and services respectively. The national courts referred the cases to the ECJ in order, effectively, to determine how to resolve the conflict between free movement and the right to take collective action.

The Grand Chamber of the ECJ released the two decisions within a week of each other in December 2007. Both extolled the fundamental nature of the right to take collective action. Referring to the European Social Charter, ILO Convention 87, the Community Charter of the Fundamental Social Rights of Workers, and the Charter of Fundamental Rights of the European Union, in both cases the Court recognized the right to take collective action, including the right to strike, as 'a fundamental right which forms an integral part of the general principles of Community Law'. ${ }^{90}$ However, the Court went on to hold that the exercise of the right was subject to certain restrictions. Here the Court turned to Article 28 of the Charter of Fundamental Rights of the European Union, which subjects the right to collective action to those restrictions imposed by national law and practices and Community law. ${ }^{91}$ The Court also decided that free movement provisions applied horizontally to the unions' actions, which not only had important consequences for liability, it meant that the unions had to justify that the aim of their actions were legitimate and that the actions were proportional. In both cases, the Court adopted a strict approach to proportionality. ${ }^{92}$ Although the ECJ recognized that the right to take collective action in order to protect workers from social dumping constituted a legitimate objective that could constitute a restriction of the freedom of

88 Case C- 438/05, International Transport Workers' Federation, Finnish Seamen's Union v Viking Line ABP, OÜ Viking Line Eesti. [2007] ECR I-10779

${ }^{9}$ Case C- 341/05, Laval un Partneri Ltd v Svenska Byggnadsarbetareförbundet, Svenska Byggnadsarbetareförbundet, avd. 1, Svenska Elektrikerförbundet, [2007] ECR I-11767.

90 Viking (n 88), para. 44; Laval (n 89) paras. 90, 91

91 Ibid.

92 C Barnard, 'A Proportionate Response to Proportionality in the Field of Collective Action' (2012) 37 European Law Review 117. V Velyvyte, 'The Right to Strike in the European Union after Accession to the European Convention on Human Rights: Identifying Conflict and Achieving Coherence' (2015) 15 Human Rights Law Review 73, 87-90. 
establishment or services, the limitations it imposed on the right's exercise almost completely nullified it.

In Viking and Laval the ECJ made reference to other human rights instruments an attempt to legitimate the status of its decisions regarding the fundamental nature of the right to strike. ${ }^{93}$ However, this striving for a kind of crosslegitimacy did not lead to normative convergence. In fact, it served to illustrate the indeterminacy of fundamental rights and to emphasize the different contexts and expertise of the different bodies.

The ILO's Committee of Experts' treatment of a complaint involving the spillover effects of the ECJ's decisions in Viking and Laval illustrates increasing normative divergence regarding the interpretation of labour rights within a polycentric legal space. ${ }^{94}$ After British Airways announced that it was going to launch a subsidiary that would operate outside of the UK, a dispute arose between it and the union representing its pilots, the British Airlines Pilots Association (BALPA), about terms and conditions of work for its members in the new subsidiary. ${ }^{95}$ When the union threatened strike action in an attempt to resolve the impasse, BA claimed that it would be in violation of the freedom of movement as established by the ECJ in Viking and Laval. BALPA brought the matter to the attention of the CEACR instead of continuing with litigation it initiated before the UK courts to determine whether those decisions were applicable to the situation. The difference between the CEACR's approach to the relationship between the right to collective action and economic freedom and that of the ECJ was stark. Although the ILO Committee began its observations by acknowledging that 'its task is not to judge the correctness of the [CJEU's] holdings in Viking and Laval', it expressed serious concern 'that the doctrine that is being articulated in these ECJ judgments is likely to have a significant restrictive effect on the exercise of the right to strike in practice in a manner contrary to the Convention'. ${ }^{96}$ It also made clear its disagreement with using the proportionality doctrine to assess the permissible restrictions on the right to strike at a national level. Similarly, in its observations on the final judgment by the Swedish Labour Court in which the Laval union was ordered to pay damages for what was at the time of its action lawful under Swedish law, the CEACR also distanced its analysis of labour rights from that of the European Court. These cases squarely present 'the problem that can arise when one country is signatory to several treaties and conventions emanating from different entities, and in a specific case, these different entities view the meaning of the same human rights

93 Ö Edstöm, "The Rights to Collective Action - in Particular the Right to Strike - as a Fundamental Right' in M. Rönnmar (ed), Labour Law: Fundamental Rights and Social Europe (Hart Pub 2011) 72.

${ }^{94}$ Kilpatrick (n 11)

${ }^{95}$ K Ewing and J Hendy, 'The Dramatic Implications of Demir and Baykara' (2010) 39 Industrial Law Journal 2.

${ }^{96}$ ILO CEACR Report (2010) 208-9; ILO CEACR Report (2011) 187. 
differently'. ${ }^{97}$ As we will see, as European unions rely on an broadening array of legal institutions in which to vindicate labour rights as human rights this problem is recurring.

Despite the suggestion in the opinion of the Advocate General in Commission $v$ Germany that the CJEU should take a more symmetrical approach to interpreting fundamental rights and freedom of movement such that that the latter do not always trump the former, the Court has continued to place economic freedoms above fundamental labour rights in the EU hierarchy. ${ }^{98}$ The apparent inability of the Luxembourg court to move away from an interpretive stance that emphasises economic freedoms has led commentators to advocate that the European Court of Human Rights be given 'a solid juridical basis that would allow it to establish itself in a new role as guardian of fundamental social rights'. ${ }^{99}$

\section{The European Court of Human Rights and an Integrated Approach}

The turn to the Strasbourg Court as a way of integrating labour rights more deeply and fully into the EU's constitution signifies the extent to which the ECtHR's approach to interpreting freedom of association in relations to collective bargaining and collective action has changed over recent years. Its jurisprudence has followed a trajectory similar to that of the Supreme Court of Canada. ${ }^{100}$ From a position that rejected that the right to strike was protected by the freedom of association contained in Article 11(1) of the European Convention on Human Rights (ECtHR), it gradually extended the scope of protection to associational activities in the labour context to include both the rights to bargain collectively and to strike. Moreover, like its Canadian counterpart, the ECtHR began to invoke the interpretation of freedom of association provided by the ILO's supervisory bodies in order to justify a change in approach to labour rights, although, in contrast to the Canadian Court, it has not insisted that the instrument be ratified.

The ECtHR's 2008 decision in Demir and Baykara v. Turkey stands in marked contrast to the approach to labour rights adopted by the ECJ in Viking and Laval.101 At issue was the lack of express statutory provisions in Turkey recognizing a right for trade unions formed by civil servants to enter into legally enforceable collective agreements. ${ }^{102}$ The Grand Chamber referred to ILO Convention 98 and the European

97 J Bellace, 'Human Rights at Work: The Need for Definitional Coherence in the Global Governance System' (2014) 30 The International Journal of Comparative Labour Law and Industrial Relations 175, 193

98 Case C-271/08, [2010] ECR I-7091, P Sypris, 'Reconciling Economic Freedoms and Social Rights-The Potential of Commission v Germany (Case C-271/08, Judgment of 15 July 2010)' (2011) 40 Industrial Law Journal 229.

${ }^{99}$ A Supiot, 'The Sense of Measure' (2010) 19 Social \& Legal Studies 220, 223

100 S Robin-Olivier, 'Normative Interactions and Development of Labour Law: A

European Perspective'(2008-09) 11 Cambridge Yearbook of legal Studies 377;

Kilpatrick (n 11) 296-7.

101 Demir and Baykara v Turkey (2009) 48 EHRR 54.

${ }^{102}$ Ibid. paras. $13-53$. 
Charter of Fundamental Rights as the basis for understanding the right to collective bargaining in the context of the freedom of association. ${ }^{103}$ The Court also made it clear that in searching for common ground among the norms of international law it has never distinguished between sources of law according to whether or not they have been signed or ratified by the respondent State. ${ }^{104}$ It adopted an approach that simultaneously confirmed the freedom of states to develop their own collective bargaining systems, and identified ILO standards and jurisprudence as providing minimum labour rights for the forty-seven members of the Council of Europe.

Shortly after it released Demir and Baykara, the ECtHR followed this broader approach that relied on international human rights in four cases involving collective action. ${ }^{105}$ Enerji Yapi-Yol Sen v. Turkey involved an executive order that prohibited public servants upon pain of discipline from taking part in a one-day national strike as part of their campaign for a collective agreement. ${ }^{106}$ The ECtHR relied upon the European Committee of Social Rights jurisprudence regarding the interpretation of the right to strike in Article 6(4) of the European Social Charter. The Court noted that strike action constitutes an important aspect of the protection of trade union members' interests, is recognized by ILO supervisory bodies as 'an indissociable corollary of the right of trade union association that it protected by ILO Convention 87,' and is enshrined in the European Social Charter as 'a means of ensuring the effective exercise as the right to collective bargaining'.107 It held that strike action was protected under Article 11(1). ${ }^{108}$ Although it acknowledged that the right to strike was not absolute and that a restriction could be justified if it answered a pressing social need and was not disproportionate, in this case the Court found that the Turkish government failed to demonstrate the general and absolute ban on all public sector workers from striking was a necessary restriction.

The difference in approach taken by the two European courts to collective bargaining, collective action, and trade unions is stark. While both courts refer to many of the same human rights instruments, their treatment of international law is very different. The ECtHR, for example, engaged with ILO supervisory body jurisprudence and used it explore the positive obligations of states to protect collective bargaining, whereas the ECJ simply invoked ILO Conventions at the level

103 Ibid. paras. 37-52.

104 Ibid. para. 77.

105 None of the subsequent cases was a decision of the Grand Chamber. Danilenkov $v$ Russia, Application no 67336/01, 30 July 2009; Enerji Yapi- Yol Sen v Turkey, Application no 68959/01, 21 April 2009; Saime Özcan v Turkey, Application no 22943/04, 12 Sept 2009; Kaya and Seyhan v Turkey, Application no 30946/04, 15 Sept 2009; Danilenkov v Russia, Application no 67336/01, 30 July 2009., which are discussed in Ewing and Hendy, (n 95) ; Fudge, ' Constitutionalising Labour Rights in Europe' (n 12); F. Dorssemont, 'The Right to Take Collective Action under Art. 11 ECHR' in F. Dorssemont, K Lörcher and I Schömann (eds), The European Convention on Human Rights and the Employment Relation (Hart Publishing 2013). .

${ }^{106}$ Enerji Yapi-Yol Se (n 105).

107 Ibid. para. 32.

108 Ewing and Hendy (95) 14 
of general right and neglected nuance and detail. ${ }^{109}$ Moreover, the two courts take opposite approaches to proportionality in the context of limitations on the existence or exercise of labour rights. This divergence in the approaches of Europe's two constitutional courts to the treatment of human/labour rights have fueled the desire by several labour commentators to use the EU's commitment to accede to the European Convention on Human Rights to bind the CJEU to the ECtHR's jurisprudence. ${ }^{110}$ The Charter on Fundamental Rights also provides a way to link the jurisprudence of the two courts more closely, and to give the ECtHR's jurisprudence greater force when it comes to human rights at the CJEU.111

In 2009, the Charter of Fundamental Rights became legally binding as part of the Treaty of Lisbon. Unlike the Canadian Charter of Rights or the European Convention on Human Rights, the EU Charter is not directly enforceable by individual complaints resolved through adjudication. It does, however, impose obligations on Member States in a limited set of circumstances, such as when a EU obligation requires Member States to take action or when a Member State derogates from EU law. ${ }^{112}$ Further, Article 52(3) of the Charter explicitly regulates the relationship between the Luxembourg and Strasbourg courts, and there is a strong argument that the Charter cannot be interpreted in such a way that derogates from the level of protection guaranteed by the European Convention of Human Right as interpreted by the ECtHR. 113

However, to date the limited evidence available indicates that the CJEU is unlikely to use the collective labour rights provisions in the Charter of Fundamental Rights to constitutionalise labour rights. In the few cases in which the labour rights in the Charter were, or could have been, in play, the CJEU has been unwilling to take any step that would give these rights an independent legal bite. ${ }^{114}$ The Charter has

109 Fudge, 'Constitutionalising Labour Rights in Europe' (n 12) 260-2.

$110 \mathrm{~N}$ Busby and R Zahn, 'The EU and the ECHR: Collective and Non-discrimination Labour Rights at a Crossroad?'(2014) 30 The International Journal of Comparative Labour Law and Industrial Relations 153; Velyvyte (n 92) 91. In December 2014, the CJEU delivered its Opinion on the draft agreement setting out the terms of the EU's accession to the ECtHR, and declared that the draft agreement was incompatible with EU law because it failed to recognize the exclusive jurisdiction of the ECJEU to interpret and apply EU law. Opinion 2/13 (Full Court), 18 December 2014, http://curia.europa.eu/juris/liste.jsf?pro=AVIS\&num+C2/13, accessed $10 \mathrm{March}$ 2015.

111 Article 52(3) accords deference to the ECtHR jurisprudence on Convention rights.

112 Zahn and Busby (n 110) 162-3.

113 M Schlachter, 'The European Social Charter: could it contribute to a more Social Europe' in N Countouris and M Freedland (eds), Resocialising Europe in a Time of Crisis (Oxford University Press 2013); Busby and Zahn (n 110) 163-4; Velyvyte (n 92).

114 For a discussion of the cases under Articles 27 and $28 \mathrm{f}$ the Charter see Busby and Zahn (n 110) 168-9; J Prassl, 'Freedom of Contract as a General Principle of EU 
also been toothless when unions have attempted to use it to challenge reforms to Member State labour laws (such as reducing pensions, public sector salaries, or dismissal protection) that were required as a condition of loans to get them through their sovereign debt crisis. ${ }^{115}$

By contrast, unions have had a great deal of success using the Council of Europe's Social Charter both to challenge loan conditionality requirements that lower labour standards and to vindicate collective labour rights as fundamental human rights. ${ }^{116}$ Unlike its civil and political rights counterpart, the European Convention on Human Rights, the Social Charter provides a menu of rights from which states could choose to be bound and did not confer individual rights or an adjudicative system. ${ }^{117}$ The adoption of Collective Complaint Procedure in 1995 enabled specifically listed organisations to bring a case against a state that has accepted the collective procedure. Composed of independent international experts, the European Committee on Social Rights (ECSR) has the exclusive competency to assess legally whether the Social Convention's requirements have been met. But, the ECSR jurisdiction is limited to a finding of non-compliance, and it has no enforcement powers. The only consequence of a finding of non-compliance is political; the Committee of Ministers has the discretion to issue a recommendation to a state. 118

Law? Transfers of Undertakings and the Protection of Employer Rights in EU Labour Law' (2013) Industrial Law Journal 434.

115 For a discussion of these cases see C Barnard, 'The Charter in a Time of Crisis: A Case Study of Dismissal' in N Countouris and M Freedland, (eds), Resocialising Europe in A Time of Crisis (Oxford University Press 2013) ; Dukes (n 5) 187-190; C Kilpatrick and B DeWitte, 'A Comparative Framing of Fundamental Rights Challenges to Social Crisis Measures in the Eurozone, European Policy Studies, Swedish Institute for European Policy Studies, November (www.sieps.se); C O'Cinneide, 'Austerity and the Faded Dream of a "Social Europe"' in A. Nolan (ed), Economic and Social Rights after the Global Financial Crisis (Cambridge University Press, 2014) 169. Similarly, the ECtHR has been unwilling to consider the austerity measures in cases brought before it: Koufaki and Adedy v. Greece (dec.) - 57665/12 and $\underline{57657 / 12}$, May 2013. For a detailed discussion see N Bruun, K Lörcher and I Schömman (eds), The Economic and Financial Crisis and Collective Laobur Law in Europe (Hart 2014).

116 Kilpatrick and De Witte (n 115) 6; O'Cinneide (n 115). For a discussion of the conflicting approaches taken by different human rights bodies to the austerity measures see Steering Committee for Human Rights, The Impact of Economic Crisis and Austerity Measures on Human Rights in Europe: A Preliminary Study on Existing Standards and Outstanding Issues, Council of Europe, Strasbourg, 6 June 2014, CDDH(2014)017, 13, 21.

117 Schlachter (n 113) 107-8. There was a supervisory mechanism whereby a Committee reviewed the reports prepared by states in order to ensure implementation.

118 Ibid. 108. 
The 'judicialisation of the ESC monitoring system' has increased its legitimacy and influence. ${ }^{119}$ In its conclusions on national reports, the ECSR has adopted a broad interpretation of the right to bargain collectively and to strike protected in Article 6. ${ }^{120}$ However, it has tended not to develop a conceptual analysis and normative approach to these labour rights, and, instead, has referred to ILO instruments and the findings of ILO expert groups. ${ }^{121}$ Recently, it has played a prominent role in characterizing labour rights as fundamental human rights. However, the ECSR has tended to be treated as the ECtHR's 'little sister'; European governments have, by and large, ignored its case law, few have ratified the collective complaints procedure, and the Committee of Ministers has been reluctant to recommend that states take action to respond to ECSR finding of non-conformity. 122

The discrepancy between the robust normative stance of the ECSR and its weak enforcement powers is captured in the Swedish government's response to the ECSR's finding that it had violated the labour rights guaranteed by the European Charter of Social Rights. Swedish unions brought a claim under the collective complaint procedure that the recent amendments to Swedish law in response to the Laval decision violated the right to strike protected in the ESC. Not only did the ECSR decision contain an extensive review of ILO standards, it went further than the ILO's CEACR in its willingness to be explicit in subjecting a Member State's legislative response to a judgment of the CJEU to scrutiny for compliance with the ESC. ${ }^{123}$ Adopting an interpretation of the right to strike that was very similar to that of the ILO supervisory bodies, the ECSR found by a vote of 13 to 1 that the Swedish legislation violated Article 6(4) of the European Charter of Social Rights, which protected the right to strike, and the Committee of Ministers endorsed its decision. ${ }^{124}$ The Swedish government responded by complaining that the ECSR's decision 'creates an unnecessary tension between the obligations of EU Member States to respond to EU law and the obligations to respect the Charter'. ${ }^{25}$ It noted that by questioning the legality of the lawful implementation of EU law under the Charter, the ECSR had put Sweden in 'an indelicate position'.126

119 Kilpatrick (n 11) 298; O’Cinneide (n 115).

${ }^{120}$ Busby and Zahn (n 110) 160.

121 Ibid. 161, citing S Evju, 'The Right to Collective Action under the European Social Charter' (2011) 3 European Labour Law Journal 200, 203; O'Cinniede (n 115). For a discussion of the Committee's approach to the right to strike see A M Świątkowski, 'Resocialising Europe through a Right to Strike' in N Countouris and M Freedland (eds), Resocialising Europe in a Time of Crisis (Oxford University Press 2013) 390. 122 O'Cinniede (n 115).

${ }^{123}$ Swedish Trade Union Confederation (LO) and Swedish Confederation of

Professional Employees (TCU) v. Sweden Collective Complaint No 85/2012, 3 July 2013, para. 120.

124 Resolution CM/ResChS (2014)1, Swedish Trade Union Confederation (LO) and Swedish Confederation of Professional Employees (TCO) v. Sweden, Complaint No. 85/2012, 5 Feb. 2014.

125 Ibid.

${ }^{126}$ Ibid. 
Given the thick web of legal linkages between the different human rights systems in the EU, the discrepancy between the interpretation and application of fundamental collective labour rights is a wicked problem. ${ }^{127}$ One solution that has been advocated and that finds some support in the labour rights jurisprudence and the practices of international and transnational human rights bodies is to treat the elaborations and observations of the ILO's supervisory bodies as the interpretive lodestar. Within the UN system, the ILO, which has a distinctive tripartite structure, is widely deferred to, and the WTO has accorded it the preeminent position to expound upon the meaning of human rights. ${ }^{128}$ The series of decisions emanating from the ECtHR beginning with Demir and Baykara in which the Court relied on the observations of ILO supervisory bodies to give meaning to freedom of association is the acme of this integrated and unified approach.

Despite the hope inspired by these decisions, it is now clear that the Court does not feel bound to adopt the same conclusions as these bodies. In RMT $v$ United Kingdom, the ECtHR held that the ban on secondary action in the United Kingdom was a justified interference with the right to freedom of association in Article 11 of the European Convention on Human Rights. ${ }^{129}$ The ECtHR referred to ILO Convention No 87, Article 6 of the European Social Charter, and its earlier decision in Demir in order to reject the UK's argument that Article 11 did not apply at all to secondary action. It also accepted the CEACR's 'role as a point of reference and guidance for the interpretation of certain provisions' of Convention 87 on freedom of association. ${ }^{130}$ Nevertheless, the Court concluded that 'the negative assessments made by the relevant monitoring bodies of the ILO and European Social Charter are not of much persuasive weight for determining whether the operation of a statutory ban on secondary strikes in circumstances such as those complained of in the present case remained within the range of permissible options open to national authorities under Article 11'.131 Emphasising that the margin of appreciation was wide in the context of industrial and economic policies of the state, the Court concluded that in the circumstances of the instant case the operation of the ban did not entail a disproportionate restriction on the applicant's right under Article 11.132

127 Schalchter (n 113) 115, 116. Not only does the ECtHR refer to European Social Charter, the EU Charter of Fundamental Rights' chapters on social policy or solidarity, which contains the collective labour right's, refers to the European Social Charter and interpretations of the Charter should not derogate from the it. See also Busby and Zahn (n 110) 161-3.

${ }^{128}$ T Novitz, "The Internationally Recognized Right to Strike: A Past, Present and Future Basis upon Which to Evaluate Remedies for Unlawful Collective Action?' (2014) 30 International Journal of Comparative Labour Law and Industrial Relations 357, 359; Bellace (n 97) 197.

${ }^{129}$ National Union of Rail, Maritime and Transport Workers v United Kingdom (application No 31045/10, 8 April 2014).

130 Ibid. para. 97.

131 Ibid. para. 98.

132 The Grand Chamber refused to accept a referral from the Chamber decision. In subsequent cases, the ECHR has continued to interpret Article 11 to include 
While it is possible to speculate that a number of factors account for the Court's change in how it treated the relevant acquis of the ILO and Social Charter, not least the UK government's threats to withdraw from the European Convention, this decision makes it clear that the meaning of the values embodied in rights instruments changes depending upon the adjudicative context. ${ }^{133}$ The ECtHR's emphasis on the fact-bound nature of its decision-making, in contrast to the ECSR's and CEACR's broader and more general assessments, have led some commentators to suggest the need both to carefully select future Article 11 complaints and to adopt an incremental strategy. ${ }^{134}$ Others have proposed the need to lodge complaints with the ILO's Committee on Freedom of Association as a way of obtaining more precise answers about whether or not particular statutory restrictions violate the right to strike. ${ }^{135}$ But the experience in Canada, where these litigation strategies are well established, suggests that courts prefer to use the international human rights instruments and the observations of human rights supervisory bodies as a source of principles and general guidelines, rather than as the solution to a particular dispute. Even more significantly, the different approaches of the various human rights bodies suggest that there is a deeper problem. International human and labour rights do not function as Platonic Forms; instead, the meaning of the values embodied in the international and European rights instruments is contested, contingent, and provisional. ${ }^{136}$

protection of the right to strike, and in doing so it has referred to international human rights instruments, the observations of ILO supervisory bodies such as the Committee on Freedom of Association, the European Charter of Social rights , and the decisions of the ECSR. In these cases the Court was not as deferential to the national limitations on the exercise of the right as it was in the RMT case. In Tymoshenso v. Ukraine (application no 48408/12) 2 October 2014, the Fifth Section, in a unanimous decision, made extensive reference to this material, and in Hrvatyski Liječnički Sindikat v. Croatia (application no 36701/09) 27 November 2014, although the majority of the First Section did not refer to the ILO and ESC jurisprudence, it was extensively discussed in a concurring decision. $133 \mathrm{~J}$ Hendy and M Ford, 'RMT v United Kingdom: Sympathy Strikes and the European Court of Human Rights' (OxHRH Blog, 10 April 2014) $<$ http://ohrh.law.ox.ac.uk/?p=5214> [7 March 2015]; A Bogg and K Ewing, 'The Implications of the RMT Case' (2014) 43 Industrial Law Journal 221.

${ }_{134}$ Kilpatrick (n 11) 317, n 81.

135 Bogg and Ewing (n 133) 250.

${ }^{136}$ Bogg and Estlund argue that the freedom of association 'as it is embodied in the ILO instruments and committee decisions should not be regarded as some kind of Platonic form.' A Bogg and C Estlund, 'Freedom of Association and Right to Context; Getting Back to Basics' in A Bogg and T Novitz (eds), Voices at Work: Continuity and Change in the Common Law World (Oxford University Press 2014) 141 at 159. I consider the status of any normative theory or understanding of human rights in contestable, provisional, and contextual. 


\section{The Challenge to the ILO's Supervisory Machinery and the Legal Status of the Right to Strike}

The most obvious illustration of the contested and provisional meaning of international labour rights is the on-going controversy at the ILO regarding the right to strike and the authority of the ILO's Committee of Experts. In June 2012, the International Organization of Employers (IOE), one of the three constituents of the ILO (along with Member States and the Workers' Group), interrupted the usual proceedings of the annual International Labour Conference, which is the ILO's legislative forum, to challenge the right to strike. ${ }^{137}$ Although this challenge was not unprecedented - since 1989 the IOE has regularly voiced opposition to the right to strike - it was the most dramatic. ${ }^{138}$ The employer group refused to examine any case of serious non-compliance involving Convention 87 in the Tripartite Committee on the Application of Standard (CAS), which examines the reports of the Committee of Experts. The IEO claimed, correctly, that the right to strike is not expressly protected in Convention 87 on Freedom of Association, ${ }^{139}$ and, further and more controversially, that the ILO's Committee of Experts, which interpreted freedom of association as including by necessary implication the right to strike, does not have the legal mandate to interpret conventions. ${ }^{140}$ Since the Workers' Group refused to accept the IOE's condition, for the first time in its history the CAS did not examine an individual case.

Why did the IOE challenge the existence of the right to strike in Convention 87 and why did it target the CEACR? Although the IOE has accepted the existence of the right to strike on a national level in many jurisdictions, ${ }^{141}$ it refuses to accept the authority of the CEACR to establish an international approach to collective action. Moreover, it appears that the IOE has targeted the CEACR because unlike the CFA, which is a tripartite body that deals with individual complaints that are brought before it, the Committee of Experts is an independent body of legal experts that comments on the implementation of conventions by Member States. The perception that the CEACR is more of a legal than political body enhances the legitimacy of its published observations, which are being relied upon by other adjudicative bodies and being given hard effects by courts. Moreover, "by attacking the inclusion of a right to strike in Convention No 87, the IOE is seeking to avoid examination of its

137 LaHovary (n 10).

138 Ibid. Typically the IOE registered an objection.

139 The 'right to strike' is not mentioned in either the ILO Constitution or in the two fundamental Convention No 87 and Convention No 98 concerning the Application of the Principles of the Right to Organise and to Bargain Collectively, 1949.

${ }^{140}$ It is clear from the ILO's constitution that the International Court of Justice as the exclusive authority to interpret ILO conventions. However, as LaHovary (n 10) 325 explains, since the CEACR has been charged with evaluating the implementation of conventions and this task inevitably involves a degree of interpretation.

${ }^{141}$ This Statement is from the end of the session of the Committee on the Application of Standards. Record 19, Part I/35, para. 147), as quoted in Bellace (n 137) 30. 
application by the Committee of Experts and the CAS'.142 By contrast, the tripartite CFA's process depends upon complaints being brought before it, and it operates by consensus, which provides the IEO an opportunity to influence the CFA's 'jurisprudence' in a less public manner. ${ }^{143}$

Following this challenge, the Committee of Experts stated that it does not claim to be able 'to give definitive interpretations of Conventions' since the ILO's constitution vests this competence in the International Court of Justice. ${ }^{144}$ However, the Committee did go on to state that in so far as the International Court of Justice does not contradict its views, they should be considered as valid and generally recognized. Unsurprisingly, this statement did not appease the Employers Group. Although it agreed in 2013 to discuss a list of cases in the Conference Committee on the Application of Standards, it insisted that there could be no comment on the right to strike.

Moreover, this challenge has been raised before other supervisory bodies, such as the ECHR and the ECSR. In the RMT case before the ECtHR, the UK government argued that because of the on-going disagreement about the status of a right to strike in the ILO and the non-binding nature of the Committee of Expert's opinions, the European Court of Human Rights should reconsider relying on the Committee's interpretation of certain provisions of the Convention on freedom of association. The Court's response was to observe that the disagreements at the ILO originated with and were confined to the employer's group. It also rejected the UK government's argument that the on-going disagreement about the status of a right to strike in the ILO, when combined with the ILO Committee of Experts' acknowledgement that its opinions are not binding, should require the ECtHR to reconsider the Committee's 'role as a point of reference and guidance for the interpretation of certain provisions of the Convention'. ${ }^{145}$ However, it is important to recall that, despite this comment, in RMT the European Court did not follow the position of the ILO and European supervisory bodies that the UK's ban on secondary action violated the right to strike. Moreover, the IOE and Business Europe, which represents employers at the EU, brought the controversy about the legal status of the right to strike to the attention of the ECSR during its consideration of the complaint by Swedish unions that the Swedish government's response to Laval violated the right to strike in the European Social Charter. ${ }^{146}$

In 2013, the Canadian employers' representative to the ILO informed the CAS that the Committee of Experts' imposed a "one-size-fits-all" vision of freedom of

\footnotetext{
142 LaHovary (n 10) 354

${ }^{143} \mathrm{C}$ LaHovary, 'A challenging ménage à trois? Tripartism in the International Labour Organisation' draft on file with the author.

${ }^{144}$ CEACR, Collective Bargaining in the Public Service: A Way Forward ILC, 102 and Session (2013) 1-2; Novitz (n 128) 374.

145 RMT (n 129) para. 97. However, the concurring opinion of Judge Wotjyczek (Ibid., para 8) criticized the Grand Chamber's approach to international labour rights in Demir and referred to the IOE's challenge to the legal status of the right to strike as provided in Convention 87.

146 Novitz (n 128) 375.
} 
association without regard to the unique and established features of the Canadian labour relations system'. ${ }^{147}$ Emphasising the fact that the right to strike is not expressly stated in the freedom of association convention, the employers' representative also noted that Canadian courts had so far refused to find that the right to strike was constitutionally protected. For these reasons, Canadian employers informed the CAS 'that it would be entirely inappropriate to conclude that the carefully tailored restrictions on the strike activity, as adopted by democratically elected legislatures and consistently reaffirmed by independent courts, violated a "right to strike"'.148

The Supreme Court of Canada's subsequent decision that the right to strike is constitutionally protected is likely to have shaken Canadian employers' preference for national approaches to interpreting the right to strike over those of the CEACR. Not only did the majority decision refer to international labour rights instruments and the observations of ILO supervisory bodies in support of the view that freedom of association included the right to strike, it simply ignored the employers group's claim that the right to strike is not part of the ILO's acquis. This approach is in marked contrast to that adopted in the dissenting judgment, where Rothstein J. claimed the 'current state of international law on the right to strike in unclear'. ${ }^{149}$

The ILO's Governing Body's response to the IOE's attack on the right to strike was to convene a three-day tripartite meeting on February 2015 to consider the interpretation of Convention 87 and the right to strike. In light of the opposition of the IOE and many governments, the workers' representatives were unable to have the interpretive question referred to the International Court of Justice. Instead, the social partners negotiated a solution to the three-year impasse over the right to strike, which begins with the statement that 'the right to take industrial action by workers and employers in support of their legitimate industrial interest is recognized by the constituents of the International Labour Organization'.150 The agreement also acknowledges that the CEACR is an independent body composed of legal experts, which in undertaking its impartial and technical analysis of how the Conventions are applied in law and practice in Member State, issues non-binding determinations of the scope, content, and meaning of the provisions of Conventions. However, despite the conciliatory tone and laudatory description of the CEACR's role, in effect, the agreement simply defers answering the sticky jurisdictional

147 CAS Observation, 102 ILC Session (2013).

148 Ibid.

${ }^{149}$ Saskatchewan Federation of Labour (n 57) 150. He also claimed that the ILO supervisory bodies, none of which exercised a judicial function, disagreed over whether or not the right to strike was included in the freedom of association, and asserted that the CAS, which was a superior body to the CFA and CEACR, "had not reached a consensus on whether the freedom of association includes the right to strike'. Ibid. para 153.

${ }^{150}$ ILO, Tripartite Meeting on the Freedom of Association and the Protection of the Right to Organise Convention, 1948 (no. 87), in relation to the right to strike and the modalities of strike action at the national level, Geneva 23-25 February 2013, TMFAAPROC/2015/2 
questions to further negotiations. Nor does it prevent the IOE from challenging, albeit in a less public but still serious way, the ability of the tripartite CFA to function.

This challenge to the IL0 has prompted some labour rights advocates to question a strategy in which the 'normative chain' for constitutionalising labour rights ends at the ILO and to urge a search for new sources of legitimacy. ${ }^{151}$ It also raises a deeper concern, which emphasizes the historically specific circumstances, namely the bargaining power of trade unions, which gave rise to the ILO's conventions and tripartite governance structure. Alan Bogg and Cynthia Estlund warn that 'the right to act through a historically particularized institution - one that exercises power and enjoys various rights even as it is embattled - can easily be caricatured by opponents as a reflection of political power of that institution rather than one of basic human rights'. ${ }^{152}$ Thus, they identify the need for 'a normative analysis of freedom of association that extends beyond traditional trade unions and is available to all people who work'.153

Recent decisions by the Supreme Court of Canada and the ECtHR suggest that in the short term the IOE's challenge to the legitimacy of the CEACR and to the legal status has been unsuccessful. But, more significantly, the longer-term impact of the challenge is to further attenuate democracy as an external form of legitimacy for contemporary constitutionalism. A distinctive feature of the ILO is that it is the only tripartite United Nations' agency - it is composed of representatives of government, employers, and trade unions. This tripartism provides the ILO with a distinctive form of legitimacy that courts lack. Although, unlike the CFA, the Committee of Experts is an expert body, which enhances its legal legitimacy, it is accountable to a body that includes workers' representatives. The same is not true of the International Court of Justice, nor, for that matter, the ECSR. The ILO is one of the very few governance institutions that constitutionally recognizes workers' voice in their own governance. While it is true that ILO is an historically embedded and specific institutional and political comprise, so, too, are all governance mechanisms, including courts.

\section{Conclusion}

The shift to international human rights and the courts by trade unions to defend collective labour rights has occurred as at the same time as trade unions political voice in the national democratic sphere has been weakened, in part through the imposition of restrictions on electoral campaign financing. ${ }^{154}$ The inability of the EU to adopt a regulation (known as Monti II) on the exercise of the right to take collective action in the context of freedom of establishment and freedom of services

\footnotetext{
151 Novitz (n 128) 378

152 Bogg and Estlund (n 136 )159.

153 Ibid.

154 K Ewing, 'The Importance of Trade Union Political Voice' in A. Bogg and T Novitz (eds), Voices at Work (Oxford University Press 2014) 277.
} 
following the controversy resulting from the Laval and Viking decisions illustrates the increasingly insurmountable hurdles to adopting a political and democratic solution to the question of the status of labour's collective rights. ${ }^{155}$ As unions have obtained support from international and transnational human rights bodies that collective bargaining and collective action are fundamental rights, employers have argued that these matters are better resolved at the national level by national courts or through legislative action. Both governments and employers' organisations have argued that democracy should trump human rights in the context of attempting to roll back labour rights. The employers' group at the ILO has also challenged the legal status of the right to strike and the authority of the ILO's independent Committee of Experts. Although national and European courts have either ignored or dismissed this challenge, refusing to renounce recourse to international labour rights as an interpretive resource, they have been careful to avoid simply adopting the decisions of ILO supervisory bodies as a basis for their decisions. While Canadian and EU Member State governments have failed to act upon the findings of international and transnational human rights bodies that wield only exhortary power, they cannot ignore the judgments of constitutional courts.

The different remedial powers of the various human rights bodies helps to account for their different approaches to the ILO supervisory bodies treatments of labour rights. Those bodies, such as the ESCR, with soft power are more likely than constitutional courts, which wield hard power, to embrace the actual findings of either the CEAR or the CFA. The internal cohesion provided to the polyarchical constitution by international human rights can only be maintained at the level of general principle. When constitutional courts invoke international human rights to give meaning to the scope of labour rights in a specific dispute they invoke a variety of interpretive techniques, such as the margin of appreciation or proportionality, in order to preserve their institutional autonomy and to avoid simply ratifying the decisions and findings of international human rights bodies.

Unions in Canada and Europe, which are creatures of the social democratic entente after World War II, are currently engaged in defensive action; they are going to court to defend what they had previously achieved through political or economic power. ${ }^{156}$ Unlike other social movements that tend to claim rights of recognition of previously denigrated and marginalized identities, unions and the labour movement also focus on issues of redistribution that go to the heart of contemporary global capitalism. ${ }^{157}$ The disappearance of a 'revolutionary' model of social justice with the

155 The Adoptive Parents, 'The Life of a Death Foretold: The Proposal for a Monti II Regulation' in M Freedland and J Prassl (eds), Viking, Laval and Beyond (Hart Publishing 2015) 95. The social partners and Member States, for different reasons, opposed the regulation.

${ }^{156}$ E Tucker, 'Can Worker Voice Strike Back? Law and the Decline and Uncertain Future of Strikes' in A Bogg and T Novitz (eds) Voices at Work (Oxford University Press 2014) 455, 472.

157 J Fudge, 'The Canadian Charter of Rights: Redistribution, Recognition and the Imperialism of the Courts' in T Campbell, KD Ewing and A Tomkins (eds) Sceptical Essays on Human Rights. (Oxford University Press, 2001) 335. The environmental 
collapse of socialism has dramatically undermined employers' consent to tripartism and social democracy. ${ }^{158}$ While sensible in the short term, in the longer term the posture of seeking to preserve what had previously been won is ill suited to meet the challenges thrown up by contemporary global capitalism. Not only does the post-war scheme of labour rights fit uneasily with the contemporary work of work, asserting labour rights in courts is insufficient to re-embed the global market in bounded social spaces. ${ }^{159}$ Although different constitutions or subsystems are autonomous, they are reciprocally related since they constitute each other's environment. Bob Jessop explains how ecological dominance occurs when 'one system in a self-organising ecology of self-organising systems imprints its developmental logic on other systems' operations more than any of the others can impose their respective logics on that system'. ${ }^{160} \mathrm{He}$ argues that the 'profit-oriented, market-mediated capitalist economy, with its distinctive self-valorizing logic, tends to have just those properties that favour ecological dominance over other types of social relations'. ${ }^{161}$ Yet, even when conditions, such as global financialisation, favour the long-term dominance of the economy, crises may result in other subsystems gaining short-term dominance. ${ }^{162}$ The key challenge is to develop democratic institutions that can survive and flourish in a globalized space, and that have the capacity to take advantage of these opportunities. While courts can, and have, provided a protected space for 'the self-constitution actions of persons and groups

movement may run into some of the same kinds of hurdles as the labour movement because both address issues at the heart of global capitalism.

158 F Maupain, 'Revisiting the Future' (2015) 154 International Labour Review 103, 113.

${ }^{159}$ J Fudge, 'Blurring Legal Boundaries: Regulating Work' in J Fudge, S McCrystal, and K Sankaran, (eds) Regulating Work: Challenging Legal Boundaries (Onati series) (Hart 2012) 1.

160 B Jessop, 'The relevance of Luhmann's systems theory and of Laclau and Mouffe's discourse analysis to the elaboration of Marx's state theory'

6, http://bobjessop.org/2014/02/09/the-relevance-of-luhmanns-systems-theoryand-of-laclau-and-mouffes-discourse-analysis-to-the-elaboration-of-marxs-statetheory/ (Accessed: 27 December 2014). Characterising it as a 'contingent emergence relationship between two or more systems rather than a naturally necessary property of a single system', Jessop identifies seven analytically distinct, but empirically interrelated, aspects of the social world that affect a system's potential to become ecologically dominant. Ibid. 6, 7.

161 B Jessop, 'What Follows Neo-Liberalism? The Deepening Contradictions of US Domination and the Struggle for a New Global Order' in R Albritton, B Jessop and Ri Westra, eds, Political Economy and Global Capitalism: The 21st Century, Present and Future (Anthem Press 2010) 75

162 Ibid. 79 
in civil society',163 they have just as readily provided even more robust protections for capital. ${ }^{164}$

Can international human rights invigorate democracy? The political debate that the Laval decision provoked in Sweden about the appropriate legislative response suggests that judicial decisions can structure wider political debates. ${ }^{165}$ Moreover, courts can provide a forum in which trade unions can exercise voice and thereby contribute to a continuous process of democratic deliberation. ${ }^{166}$ However, the democracy-enhancing potential of invoking international human rights in courts must be understood in the context of the broader functional role that courts and rights play in a globalized world, which is to substitute rights for constituent power as a basis for political legitimacy. It is also crucial to appreciate the extent to which constitutional courts have also given force to the economic constitution, which has tended to dominate the other constitutions. In Canada and in Europe, courts have become key institutions to which the future of labour rights has been entrusted. The specific court's orientation and function - is its mandate to protect fundamental human rights or to build a common market? - are critical in determining the extent to which labour rights will be given constitutional protection. Polycentrism and normative contestation characterize the contemporary human rights landscape, and different courts have different approaches to labour rights. How to resolve this normative uncertainty is not obvious. ${ }^{167}$ Rights have become free-floating signifiers in which courts through a self-reflexive process are the final arbiters of value. The shift to human rights and to courts as the basis of freedom of association exemplifies the hegemony of human rights law and the role of courts in global constitutionalism. It also reflects, rather than causes, the diminution in the legitimacy of constituent power and democratic action as a basis for political action. Unions are suffering the same fate as other democratic institutions in an era of global constitutionalism.

163 My thanks to one of the anonymous reviewers for this observation and from whom I take this phrase.

164 Fudge, 'Legally Speaking: The Courts, the Market, and Democracy' (n 15) Danny Nicol, 'Business Rights as Human Right' in T Campbell, K D Ewing, and A Tomkins (eds), The Legal Protection of Human Rights: Sceptical Essays (Oxford U P 2011). 165 M. Rönnmar, 'Sweden' in M Freedland and J Prassl (eds), Viking, Laval, and Beyond (Hart, 2014).

166 V Mantouvalou, 'Democratic Theory and Voices at Work' in A Bogg and T Novitz Voices at Work (Oxford University Press 2014) 214, 230.

167 Some commentators suggest that 'a landscape of proliferating and divergent normative regimes and standards might be a good thing'. K Rittich, 'The ILO: Challenges in Times of Crisis' (2015) 154 International Labour Review 85, 89. 